\title{
The Possible Influences of the 2012 Modena Earthquakes on the Fluorescence Spectra of Bottled Mineral Water
}

\author{
Fidani $\mathbf{C}^{1}$, Balderer $\mathbf{W}^{2}$ and Leuenberger $\mathrm{F}^{3}$ \\ ${ }^{1}$ Osservatorio Sismico, Andrea Bina, Borgo XX Giugno 74, 06121 Perugia, Italy \\ ${ }^{2} E T H$ Zurich, Swiss Geotechnical Commission, Switzerland
}

${ }^{3}$ ETH Zurich, Engineering Geology, Sonneggstrasse 5, 8092 Zurich, Switzerland

\begin{abstract}
Two moderate earthquakes with magnitudes of 6.0 and 5.8 occurred in active tectonic crustal structures of the Po Plain in the area of Modena City in Northern Italy. These events generated temporary and/or permanent environmental changes with much damage, leading to 27 deaths. These quakes occurred on May 20, 2012, at 02:03 UTC, and on May 29,2012 , at 07:00 UTC, at depths of 6.3 and $8.1 \mathrm{~km}$, respectively. In order to investigate for effects from the earthquakes on the fluorescence spectra and ion composition of groundwater within the affected area, available mineral water bottled prior to and post the two shocks were collected. Specifically, the regular production lines at the bottling plants of the brands Lieta, Ventasso, Cerelia and Monte Cimone situated in the nearest Appennine chain, contributed to this study. These bottled waters where analyzed for their fluorescence spectra using the synchronous scanning method. Variations of fluorescence intensity a month before the first earthquake of May 20,2012, appeared to be significant only at Monte Cimone spring, where high density water samples were available. Likewise, variations in ion compositions evidenced peaks at a month before the first earthquake and a month after the second one. $\mathrm{pH}$ and conductivity levels of only some springs also shown significant variations at a month before the first earthquake. These findings suggest that a realization of continuous measurement networks in areas prone to incidences by strong earthquakes could be useful for investigating any possible influence of earthquakes on water geochemistry.
\end{abstract}

Keywords: Groundwater fluorescence spectra; Groundwater ions; pH; Conductivity; Seismic hazards

\section{Introduction}

The study of the geochemical and hydrodynamic characteristics of aquifers and their changes is considered a valid contribution to the knowledge of natural processes connected to earthquakes [1]; mostly because these changes can be indicators of a both physical and chemical causes in water-rock interaction around the time of seismic activity. Researchers have developed consciousness of the ubiquitous presence and importance of fluids within the Earth's crust [2]. However, Kirby [3] has reported that the chemical effects of aqueous fluids in rocks can be heterogeneously distributed in the crust. To deduce the rheological laws for any crustal rock type under hydrothermal condition on the basis of known chemical effects of water on deformation and strengths of rocks it seemed premature from Kirby's survey [3].

From an observational point of view, over the last few decades studies focusing on the behaviour of geochemical and geophysical parameters relative to seismic activity have been intensified [4]. Of these, an investigation of relationships among the attributes of many earthquakes related to gasgeochemical and hydrogeological signals, evidenced a strong correlation between signal duration and precursory time [5]. Signals were categorized into four groups reflecting differences in monitoring station densities, measurement methods and physical processes related to signal occurrence. Signals were: the radon exhalation from the earth's crust, the exhalation of other gases, the temporal variations in water level or discharge of springs, as well as the temporal variations in temperature and dissolved ions in the water of the monitoring sites [5].

Moreover, significant results have been recently obtained from testing commercially produced bottles of drinking water collected weeks and months before quakes. Specifically, it was possible to verify that ion concentrations of ground water near the epicentre of the Kobe earthquake fluctuated before the January 17, 1995, Mw=6.8
[6,7]. For another study, mineral water samples were provided by Aguas de Cabreiroá, S. A. which exploited $\mathrm{CO}_{2}$-rich groundwater from a well $120 \mathrm{~m}$ deep, located about $90 \mathrm{~km}$ from the epicentres of the Galicia's earthquakes, on November 29 and December 24, 1995, both with a $\mathrm{Ms}=5.0$ and 5.1, respectively. The observed increased Chlorate concentration [8] was comparable to that reported for the 1995 Kobe earthquake. Even if the area where $\mathrm{Mw}=7.2$ Van earthquake occurred on October 23, 2011 was not included in the monitoring program following the Izmit earthquake, it was possible to obtain commercially bottled water samples from the EREK spring located less than 20 kilometres from the epicenter of the earthquake [9]. Chemical analysis for major ions dissolved in water showed significant variations weeks before the shock. Recently, changes in groundwater chemistry before two consecutive earthquakes in Iceland have been reported [10]. These occurred four to six months before moderate earthquakes having magnitudes greater than 5.0 in October 2012 and April 2013. The Authors recorded multiple abrupt changes in the isotopic compositions of hydrogen and Oxygen, as well as concentrations of major elements Sodium, Silicon and Calcium. Moreover, in a calcium carbonate aquifer characterised by a steady low content of most metals in Central Italy, increases in the contents of Chromium, Iron, Vanadium and Arsenic were recorded months before and during the onset of the 2016-2017 seismic sequences in the Central Italian Apennines [11].

*Corresponding author: Cristiano Fidani, Osservatorio Sismico, Andrea Bina, Borgo XX Giugno 74, 06121 Perugia, Italy, Tel: (+39)07535132; E-mail: c.fidani@virgilio.it

Received December 14, 2017; Accepted December 21, 2017; Published December 28, 2017

Citation: Fidani C, Balderer W, Leuenberger F (2017) The Possible Influences of the 2012 Modena Earthquakes on the Fluorescence Spectra of Bottled Mineral Water. Hydrol Current Res 8: 288. doi: 10.4172/2157-7587.1000288

Copyright: @ 2017 Fidani C, et al. This is an open-access article distributed under the terms of the Creative Commons Attribution License, which permits unrestricted use, distribution, and reproduction in any medium, provided the original author and source are credited. 
Citation: Fidani C, Balderer W, Leuenberger F (2017) The Possible Influences of the 2012 Modena Earthquakes on the Fluorescence Spectra of Bottled Mineral Water. Hydrol Current Res 8: 288. doi: 10.4172/2157-7587.1000288

Page 2 of 9

Our study investigated for an influence of earthquakes prior to, during and after the events on the fluorescence spectra of bottled mineral waters from local springs. Changes in the fluorescence spectra were for the first time evidenced in the context of a strong $\mathrm{Mw}=7.4$ Izmit earthquake in Western Turkey on August 17th, 1999 from samples of mineral and thermal water; which were taken in the course of another investigation just before the catastrophic event. In order to observe potential changes in chemical and isotopic constituents before and after this event, a second sampling was carried out at the same water sources about one month later $[12,13]$.

Several past works have followed the same research line. In Salò, in Northern Italy, a quake struck with a magnitude of 5.3 on November $24,2004[14,15]$. In this case, the fluorescence spectrum of several water samples collected about 17 days before the earthquake from the Tavina Mineral Spring was significantly higher compared to the reference water. Finally, a fluorometer was installed at the Brigerbad thermal spring (Switzerland), which continuously measures fluorescence over three channels of different wavelengths together with the turbidity of the water [16]. It is part of COupled seismogenic GEohazards in Alpine Regions (COGEAR) which is an interdisciplinary natural hazard project investigating the hazard chain induced by earthquakes [16].

Following the Modena earthquake, occurring just after 4 am local time [17], the only possibility to get information regarding any changes in groundwater fluorescence spectra prior to and after the quake was to analyze locally bottled mineral water prior to and after the event.

\section{Materials and Methods}

One of the most striking features of the Modena earthquake was its observed diffused liquefaction phenomena [18]. Geochemical field investigations were also carried out into the epicentral area. The soilgas concentrations and flux measurements for liquefactions, ground fractures, and collapsed caves suggested a superficial origin of these phenomena [19]. Stress field was consistent with active shortening in the Northern Italian Apennines [20], while suprahydrostatic pore pressure and $\sigma 1 \sim \sigma 2 \neq \sigma 3$ were required to reactivate the thrusts. It was supposed that the involved fluids could have been gas and brines hosted in the folded sedimentary successions [21]. To obtain a reliable set of systemmatic geochemical observations, four local water companies producing bottled water from local springs located within the Italian Appennine Chain were contacted to obtain water samples, prior to and after the two earthquakes. Carrying out an analysis of this type of water had the advantages of being bottled throughout the year and therefore available before and after an earthquake. Whereas, its disadvantage was that it was a consumer product with limited stocks, which were not always available for continuous monitoring. In light of this, to garner consistent results, the bottling plants and spring/boreholes should have been as close to the earthquake epicentre as possible. Figure 1 depicts the epicentre of the Modena $\mathrm{Ml}=6.0$ May 20, 2012 earthquake, located 60 to $80 \mathrm{~km}$ from the four bottling plants.

The limestone Appennine mountains, rising south of Modena, are known to produce high quality drinking water. Groundwater escaping from natural springs is sealed in bottles and sold on the market. The Lieta and Ventasso springs are located in Cervarezza Terme, Reggio

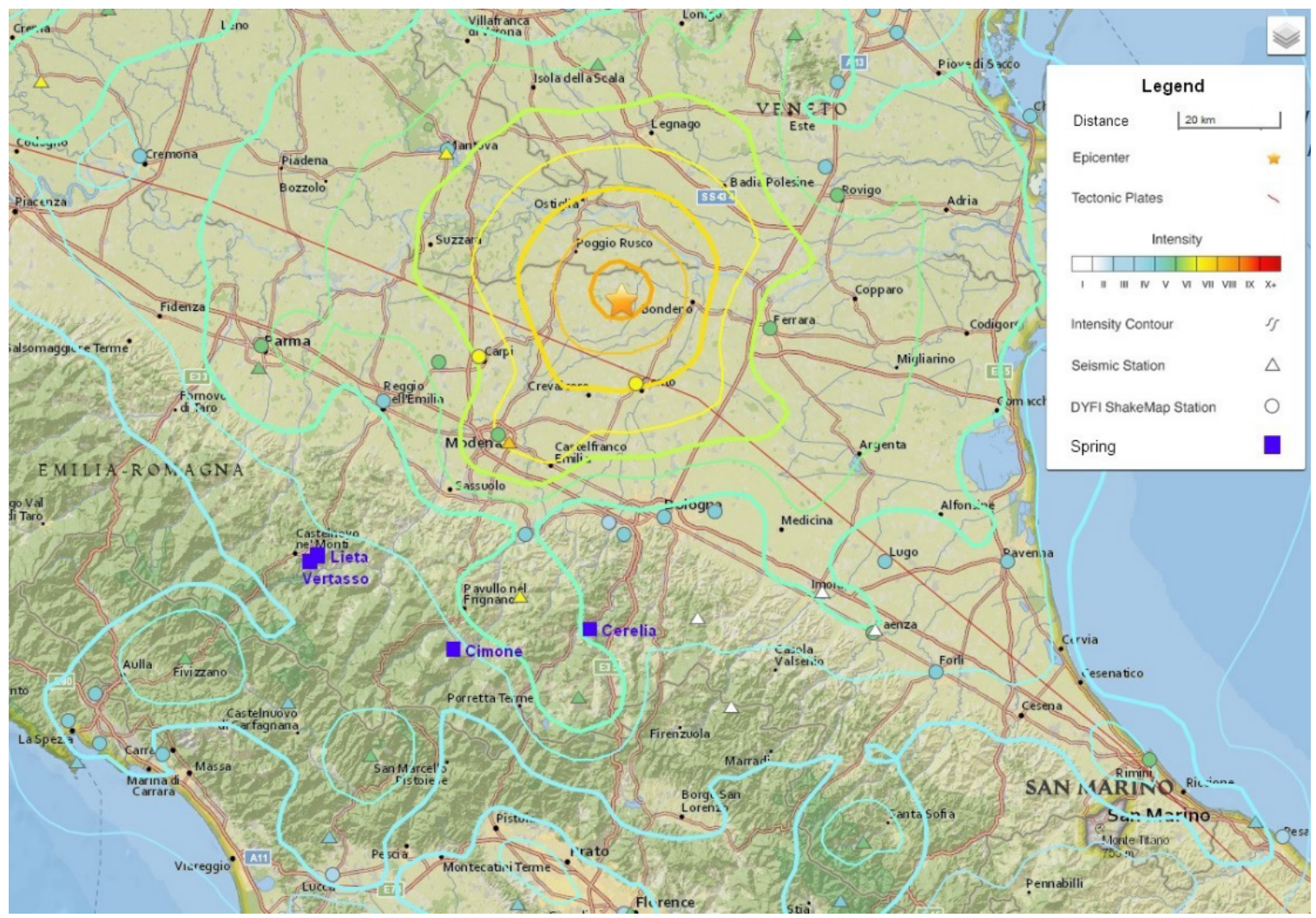

Figure 1: The intensity areal distribution due to the Modena earthquake. The epicentre is indicated by an orange star. The locations of seismic and ShakeMap stations are indicated by triangles and circles. The locations of the four mineral water plants are indicated by squares. 
Emilia Province, at coordinates $44^{\circ} 23^{\prime} \mathrm{Lat}, 10^{\circ} 16^{\prime}$ Lon, at $1030 \mathrm{~m}$ and at $1006 \mathrm{~m}$ altitudes, respectively. The temperatures at the mouths of these springs are $7.7^{\circ} \mathrm{C}$ and $8^{\circ} \mathrm{C}$, respectively. The mean ion characteristics are listed in Table 1. The Cerelia spring is located near Vergato, Bolgna Province, at coordinates $44^{\circ} 31^{\prime}$ Lat, $11^{\circ} 06^{\prime}$ Lon and at an altitude of 680 $\mathrm{m}$. The temperature at the mouth of the spring is $10.8^{\circ} \mathrm{C}$. The mean ion characteristics are listed in Table 1. The Monte Cimone spring is located in Ospitale di Fanano, Modena Province, at coordinates $44^{\circ} 10^{\prime} \mathrm{Lat}, 10^{\circ}$ $47^{\prime}$ Lon and at an altitude of $935 \mathrm{~m}$. The temperature at the mouth of the spring is $7^{\circ} \mathrm{C}$. The mean ion characteristics are reported in Table 1. Physical-chemical analysis results of the four mineral waters were compared with rainfall data collected from the same areas. All rainfall data were obtained from ARPA Emilia Romagna publication [22] pertaining to the study period. The Collagna Station $(830 \mathrm{~m})$ provided data for the Lieta and Ventasso springs. The Riola Vergato Station (256 m) supplied data for the Cerelia spring, and the Piandelagotti Station $(1,215 \mathrm{~m})$ provided data for the Monte Cimone spring.

The geological structures responsible for the seismic activity have been identified as thrust faults delineating the outer margin of the Northern Apennines. The area of earthquakes is about 30 kilometres long and 12 kilometres wide; which follows the crest of the buried Cavone-Mirandola anticline. The structures developed during Neogene and Quaternary in the framework of the collision between the European continental margin and the Adria microplate [23]. The fold-and-thrust system is completely buried by thick Quaternary sediments of the Po Plain and involving a sedimentary succession mainly consisting of Triassic evaporites, Mesozoic-Early Tertiary shallow to deep-water carbonates, and Oligocene-Miocene clastic successions [24]. Miocene strata are covered by a Plio-Quaternary deposit which is extremely variable and was controlled by the growth of thrust-propagation folds; ranging from 7,000 to $8,000 \mathrm{~m}$ at the core of the deepest synclines to about only $150 \mathrm{~m}$ at the top of thrust-related anticlines [25].

\section{Synchronous fluorescence spectrometry}

The main investigative tool in this study was the synchronous fluorescence spectroscopy. This choice was based upon the fact that this instrument had seemed to be able to previously detect significant changes in fluorescence spectral intensities of thermal and mineral waters, which were collected prior and after the Izmit earthquake on August 17, 1999, Mw=7.4, in the nearby areas of Kuzuluk, Bursa, and Yalova/Gemlik. A water sample collected weeks before the earthquake exhibited a slightly elevated $340 \mathrm{~nm}$ intensity [14]. Similar changes in fluorescence spectral intensities had been observed around the Lake Garda region in Northern Italy, following an $\mathrm{Ml}=5.3$ earthquake on November 24, 2004. In fact, the fluorescence spectrum of several water samples collected about 17 days before the earthquake, were slightly elevated at $340 \mathrm{~nm}$ and $390 \mathrm{~nm}$ peak intensities [15].

The physical process of fluorescence occurs when a molecule absorbs photons from the UV to visible light spectrum (200-900 nm), causing transition to a high-energy electronic state and then emits photons as it returns to its initial state, in less than $10^{-9} \mathrm{sec}$. Because during this process, some energy is lost through heat or vibration, the emitted energy when returning to the initial state is less than the exciting energy; e.g., the emission wavelength of the molecule is always longer than the excitation wavelength. The difference between the excitation and emission wavelengths is called the Stokes shift. Fluorescence spectroscopy can be used to reliably assess the relationship between absorbed and emitted photons at specified wavelengths. It is a selective quantitative analytical technique, which is inexpensive and easily mastered [26]. Synchronous fluorescence spectrometry consists of scanning the emitted light intensities at a constant wavelength difference between the excitation and emission wavelengths.

In order to investigate for a possible influence of $\mathrm{Ml}=6.0$ and $\mathrm{Ml}=5.8$ earthquakes of May 2012, locally sourced mineral water was obtained from local bottling plants within the affected area. These bottles were filled on production lines prior to and after the main

\begin{tabular}{|c|c|c|c|c|}
\hline & Lieta & Ventasso & Cerelia & Monte Cimone \\
\hline Temperature $\left[{ }^{\circ} \mathrm{C}\right]$ & 7.7 & 8 & 10.8 & 7 \\
\hline $\mathrm{pH}$ & 7.8 & 7.5 & 7.4 & 7.7 \\
\hline Residual $\left(180^{\circ} \mathrm{C}\right)[\mathrm{mg} / \mathrm{l}]$ & 170 & 178 & 379 & 116 \\
\hline Conductivity $\left(25^{\circ} \mathrm{C}\right)[\mu \mathrm{S} / \mathrm{cm}]$ & 250 & 241 & 599 & 195 \\
\hline Hardness $\left[{ }^{\circ} \mathrm{F}\right]$ & 12.3 & 11.4 & n.d. & 10.5 \\
\hline Oxidability [mg/l] & n.d. & n.d. & n.d. & n.d. \\
\hline $\mathrm{O}_{2}[\mathrm{mg} / \mathrm{l}]$ & n.d. & n.d. & n.d. & n.d. \\
\hline $\mathrm{CO}_{2}$ free $[\mathrm{mg} / \mathrm{l}]$ & 5 & 4.9 & n.d. & 3.2 \\
\hline $\mathrm{Ca}^{+2}[\mathrm{ppm}]$ & 41.4 & 39.2 & 121 & 33 \\
\hline $\mathrm{Mg}^{+2}[\mathrm{ppm}]$ & 4.6 & 4.6 & n.d. & 5.5 \\
\hline $\mathrm{Na}^{+}[\mathrm{ppm}]$ & 14 & 14.6 & 5.9 & 2.7 \\
\hline $\mathrm{K}^{+}[\mathrm{ppm}]$ & 0.3 & 0.2 & 0.57 & 0.7 \\
\hline $\mathrm{HCO}_{3}^{-}[\mathrm{ppm}]$ & 135 & 140 & 418 & 125 \\
\hline $\mathrm{SO}_{4}^{-2}[\mathrm{ppm}]$ & 30.9 & 24.9 & 7.6 & 9.9 \\
\hline $\mathrm{Cl}^{-}[\mathrm{ppm}]$ & 3.7 & 10.3 & 5.6 & 2.8 \\
\hline $\mathrm{NO}_{3}^{-}[\mathrm{ppm}]$ & 1 & n.d. & 1.3 & 1.8 \\
\hline $\mathrm{F}^{-}[\mathrm{ppm}]$ & n.d. & n.d. & 0.11 & n.d. \\
\hline $\mathrm{Li}^{+}[p p m]$ & n.d. & n.d. & n.d. & n.d. \\
\hline $\mathrm{Sr}^{+2}[\mathrm{ppm}]$ & n.d. & n.d. & n.d. & 0.2 \\
\hline $\mathrm{NH}_{4}^{+}[\mathrm{ppm}]$ & n.d. & n.d. & n.d. & n.d. \\
\hline I- $[p p m]$ & n.d. & n.d. & n.d. & n.d. \\
\hline $\mathrm{Br}$ [ppm] & n.d. & n.d. & n.d. & n.d. \\
\hline $\mathrm{SiO}_{2}[\mathrm{ppm}]$ & n.d. & n.d. & 15.6 & n.d. \\
\hline
\end{tabular}

Table 1: Chemical-Physical properties and mean ion characteristics of the mineral waters. 
shock took place. All the bottles were labeled with dates and times of production. Upon obtaining these bottles, they were sent to the ETHZ laboratory located in Zurich, Switzerland; at distance of $495 \mathrm{~km}$ from Bologna. The bottles were stored in a single cardboard box and kept in a cool and dark place. Upon which, the water samples were analyzed for their fluorescence spectra to investigate for intensity anomalies using the synchronous scanning method. Specifically, the Luminescence Spectrometer Perkin-Elmer LS-50B was used. The light source of this instrument emits light at a certain range of wavelength. The light passes an adaptive slit, before the excitation mono-chromator lets pass the light with the desired wavelength. Afterwards, the filtered light reaches the sample, which fills the quartz cuvette, and causes the emission of photons. The emission mono-chromator filters the light to the wavelength, which is intended to be measured. Finally, the light hits the photo-multiplier where the light intensity is converted into a fluorescent signal. A wavelength difference of $20 \mathrm{~nm}$ was applied to these investigations.

In order to compare the recorded variations in the individual measured fluorescence spectra of the individual mineral water samples Lieta, Ventasso, Cerelia and Monte Cimone, the intensities of specific wavelengths ( $329 \mathrm{~nm}, 345 \mathrm{~nm}, 373 \mathrm{~nm}$ and $390 \mathrm{~nm}$ ) which proved to be sensitive to tectonic activity by previous studies [15], were selected. These selected wavelengths are plotted in Figure 2 for the synchronous fluorescence spectra of Lieta water. Another comparative method consisted in calculating the mean of the integration of the intensities at wavelengths between $300 \mathrm{~nm}$ and $500 \mathrm{~nm}$.

The individual samples of the intensities at the selected wavelengths $329 \mathrm{~nm}, 342 \mathrm{~nm}, 373 \mathrm{~nm}$, and $390 \mathrm{~nm}$ are plotted for daily averages in Figure 3, together with the means of the integration of the intensities of the entire measured fluorescence spectra. Error bars were obtained by calculating the mean difference between daily values and daily averages, and resulted being around $2 \%$ of intensities. The plot yielded the same variation pattern for each of the intensities. The fluorescence intensities at $329 \mathrm{~nm}$ resulted being a mean of all intensities at different wavelengths, including the integration of the intensities of the entire measured fluorescence spectra.

Figures 4-6 plot the fluorescence intensities at $329 \mathrm{~nm}$ wavelengths. These intensities are plotted along with earthquake magnitudes greater or equal to 4.5 , as well as daily cumulative rainfall levels. The plotted earthquakes were selected as they were major daily earthquakes each with a Dobrovolsky radius [27] $\mathrm{r}=10^{0.43 \mathrm{M}}>80 \mathrm{~km}$; which was the maximum distance among the earthquake epicenters and the water springs. In particular, Figure 4 indicates both the Lieta and Ventasso fluorescence intensities at $329 \mathrm{~nm}$; the springs are about several hundred meters apart. Available bottling dates were slightly different, therein providing a denser set of data on April 3 and 30, on May 1, 18, 21, 22, 23 and 31, on June 1, 14 and 15, 2012, for Lieta, and on April 3, 4 and 23, on May 18, 21 and 24, on June 1, 4, 13, 14 and 24, 2012, for Ventasso.

Figure 5 depicts plotted Cerelia fluorescence intensities at 329 $\mathrm{nm}$ together with rainfall data collected by the Riola Vergato (above Vergato) Meteorological Station during the same period. Figure 5 also depicts daily major shocks with magnitudes greater than or equal to 4.5. For Cerelia, fluorescence intensities were measured only for 4 dates on March 8, on April 2, on May 18 and on June 6, 2012. Relative error bars indicate about a $2 \%$ of range of error for daily measurements.

For the Monte Cimone there was a greater number of bottled samples available, particurarly from March 6 to June 26, 2012. These

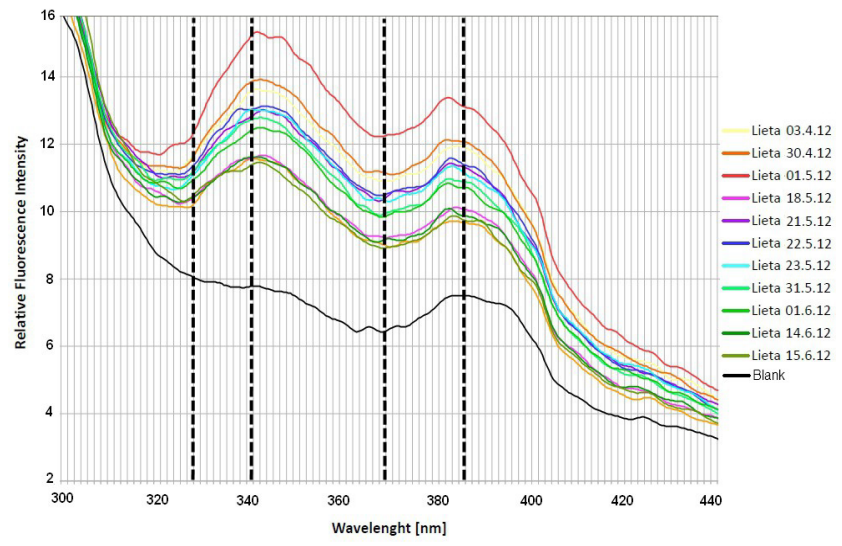

Figure 2: Synchronous scan fluorescence spectra of mineral samples from the Lieta water with their corresponding dates for bottling. Wavelengths of 329 $\mathrm{nm}, 345 \mathrm{~nm}, 373 \mathrm{~nm}$, and $390 \mathrm{~nm}$, are indicated by vertically dashed lines.

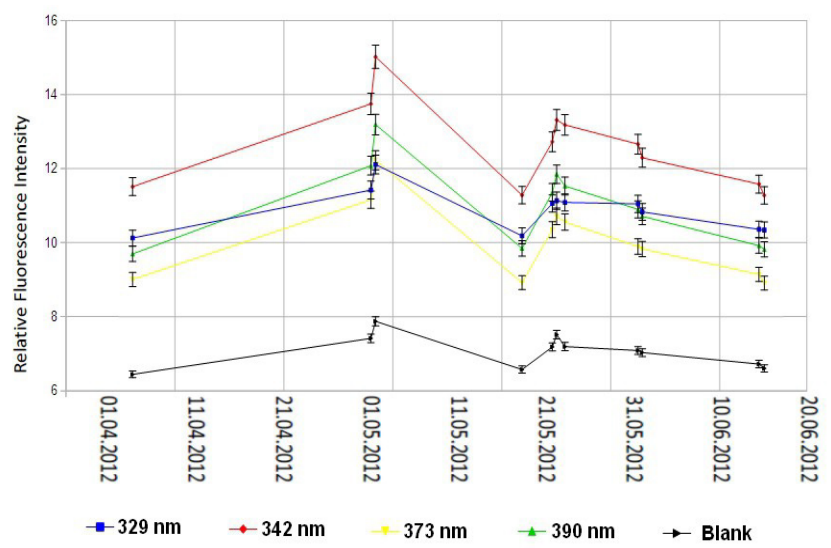

Figure 3: Fluorescence levels of Lieta water samples. Error bars are indicated in black.

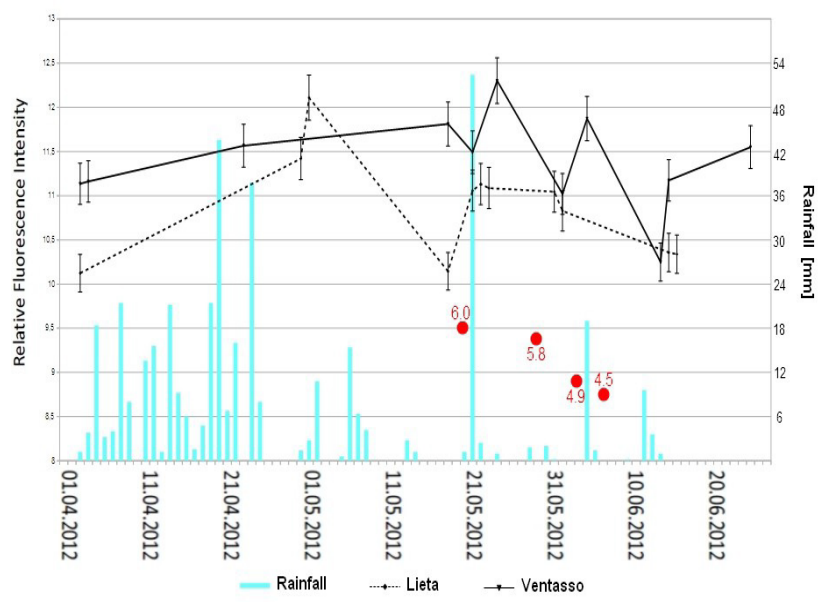

Figure 4: Earthquake dates are indicated in red, fluorescence of Ventasso and Lieta relative Intensity at $329 \mathrm{~nm}$ are indicated with black lines. Cumulative daily rainfall levels nearby the springs are shown with columns. 
dates were on March 6 and 23, on April 11, 20, 21 and 23, on May 2, 8, 9, 10, 14, 17, 18,21, 22, 23, 24, 25 and 31, on June 5, 15, 20 and 26, 2012. Figure 6 shows Cimone fluorescence intensities at $329 \mathrm{~nm}$ together with rainfall data collected by the Piandelagotti Meteorological Station, which is near Monte Cimone, and daily major shocks with magnitude greater or equal to 4.5 .

\section{Ion chromatography}

The ionic content levels of $\mathrm{F}^{-}, \mathrm{Cl}^{-}, \mathrm{NO}_{3}^{-}, \mathrm{SO}_{4}^{-2}$ as well as $\mathrm{Na}^{+}, \mathrm{K}^{+}$, $\mathrm{Mg}^{+2}, \mathrm{Ca}^{+2}$ and $\mathrm{Sr}^{+2}$ were measured with the Dionex DX-120 Ion Chromatograph. This instrument uses the principle of the mobile phase, which consists of the substance to analyze and of the eluent which flows through a stationary phase. The function of the eluent is to dissolve the ions which should be detected after they have been exchanged and bound at the stationary phase so that they can be detected. With the suppressor, the conductibility of the eluent is decreased. Finally, conductivity measurements are proportional to the ionic concentration using an electronic method. The signals are then evaluated by the Chromeleon software which integrates each peak and indicates its respective ion. Ionic content levels are shown in Figures $7 \mathrm{a}-7 \mathrm{c}$, are expressed in ppm and grouped according to defined intervals of concentrations. Errors were calculated, as above here, by calculating the mean difference between daily values and daily averages. Error estimates resulted being: $20 \%$ for $\mathrm{F}^{-}, 5 \%$ for $\mathrm{Cl}^{-}, 4 \%$ for Nitrate, $7 \%$ for Sulfate, $1 \%$ for $\mathrm{Na}^{+}, 10 \%$ for $\mathrm{K}^{+}, 2 \%$ for $\mathrm{Mg}^{+2}, 2 \%$ for $\mathrm{Sr}^{+2}$ and $1 \%$ for $\mathrm{Ca}^{+2}$. Error bars were not inserted into the plots to render the Figures more legible. Vertical red lines show the times of the earthquakes.

\section{pH and conductivity}

Conductivity and $\mathrm{pH}$ measurements are reliable and easy to use, especially for quality control purposes. Conductivity provides a rapid and inexpensive way to determine the ionic strength of a solution, by giving a reading that is proportional to the combined effect of all the ions. Surveillance of feed water purity, control of drinking water and process water quality, estimation of the total number of ions in a solution or direct measurement of components in process solution can all be obtained using conductivity measurements. These high reliability, sensitivity and relatively low cost of conductivity instrumentation makes it a potential primary parameter of any good monitoring program. Conductivity measurements cover a wide range of solution conductivity from pure water at less than $0.1 \mu \mathrm{S} / \mathrm{cm}$ to values of greater than $1 \mathrm{~S} / \mathrm{cm}$ for concentrated solutions. The $\mathrm{pH}$ level is of major importance in determining the corrosion of water. Generally speaking, the lower the $\mathrm{pH}$, the higher the level of corrosion, even if the $\mathrm{pH}$ is only one of many factors affecting corrosion. The $\mathrm{pH}$ of pure water is 7 , but the normal range for $\mathrm{pH}$ in surface water systems tends to be between 6.5 and 8.5 , while this range for groundwater systems tends to be between 6.0 and 8.5. For this study, $\mathrm{pH}$ was measured electrometrically at controlled temperatures with a glass electrode. Figure 8 shows the $\mathrm{pH}$ levels and the conductivity levels of the analyzed samples associated to the earthquake magnitudes. Conductivity errors were estimated to be between $1 \%$ and $6 \%$, whereas $\mathrm{pH}$ error estimates were calculated to be between $1 \%$ and $4 \%$.

\section{Discussion}

Fluorescence spectra of the individual Lieta water samples, see Figure 2, yielded the same variation pattern i) for the intensities of the above defined specific wavelengths as well as ii) for the means of the integrated intensities of the entire measured fluorescence spectra. These results were also obtained for the Ventasso, Cerelia and Monte

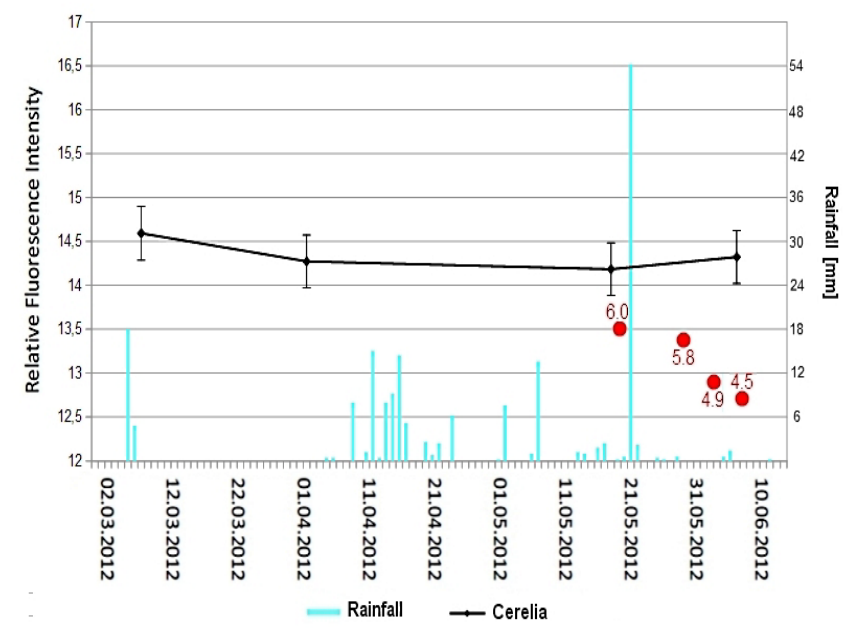

Figure 5: Earthquake date are indicated in red. Fluorescence samples for Cerelia (at $329 \mathrm{~nm}$ ) are plotted and connected by a black line. Cumulative daily rainfall levels nearby the springs are shown with columns.

Cimone water samples. The fluorescence variations of the four mineral waters at the distinct wavelength of $329 \mathrm{~nm}$ were represented according to their bottling dates together with major earthquakes. The Lieta and Ventasso peaks in fluorescence intensities were recorded on April 30, on May 24 and on June 2012 (Figure 4). However, scarcity of data did not permit a reliable isolation of these peaks. Moreover, when after having combined the data of these two springs, their maximums did not result having the same times. Additionally, a correlation was not observed between fluorescence and either the indicated seismic events or rainfall. Fluorescence intensity levels of the Cerelia samples, see Figure 5, were measured for only 4 available bottling dates on March 8, on April 2, on May 18 and on June 6, 2012. For limited data, it was not possible to investigate for a pattern in fluorescence intensity levels for the 2012 Modena earthquakes. As shown in Figure 6, significant increases in fluorescence intensity levels were recorded after April 21, 2012, and maintained up to May 30 of the same year for Monte Cimone. On May 18, 2012, few days before the main shock, there was a recorded decrease in fluorescence intensity level. Before the second strong earthquake on May 29, 2012, having a magnitude of $\mathrm{Ml}=5.8$, another significant increase in the fluorescence intensity level was recorded. Following this, in June 2012, this level sharply decreased to levels lower than those measured six months prior. Data from Monte Cimone were the most dense and they did not result being correlated to rainfall levels. Past studies have reported the out flowing charges from rocks to water might induce water changes on the surface contact between water and rocks [15,28]. Our study was unable to support this hypothesis.

Figure $7 \mathrm{a}$ depicts the ion concentration levels for Lieta and Ventasso. Several variations were observed within each group. In fact, the ion concentrations for Sodium, Sulfate and $\mathrm{Sr}$ from Lieta fluctuated weeks before the shocks. These concentrations started to decrease on month before the earthquakes and reached their maximums around May 20, 2012. Fluctuations of the same ion concentrations were less marked for Ventasso. Instead, $\mathrm{Cl}^{-}$concentrations for both Lieta and Ventasso had similar strong variations, with absolute minimums one month before the earthquakes and with stepped maximums on May 21, 2012. Slight monotone increases in Magnesium ion concentrations for both Lieta and Ventasso were recorded. Insignificant variations in Calcium, Sodium and Sulfate ionic concentrations were recorded 
Citation: Fidani C, Balderer W, Leuenberger F (2017) The Possible Influences of the 2012 Modena Earthquakes on the Fluorescence Spectra of Bottled Mineral Water. Hydrol Current Res 8: 288. doi: 10.4172/2157-7587.1000288

Page 6 of 9

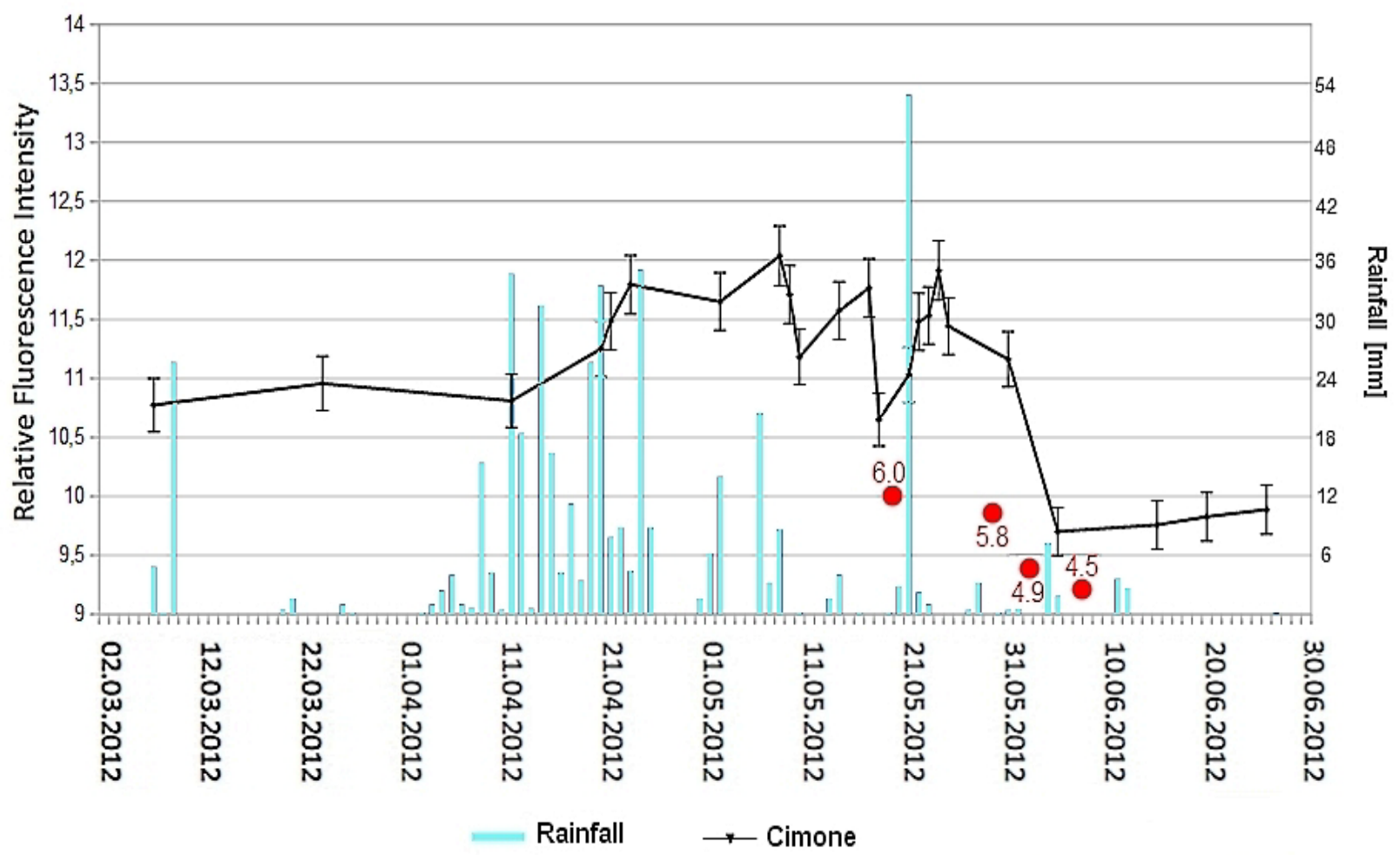

Figure 6: Earthquake dates are indicated in red. Fluorescence samples for Monte Cimone (at 329 nm) are plotted and connected in black. Cumulative daily rainfall levels nearby the spring are shown with columns.

around the time of seismic activity for Ventasso. Potassium concentrations were sharply increased for Lieta on May 21, whereas the Nitrate concentrations decreased for both Lieta and Ventasso. All the above indicated variations resulted being above the error levels for Lieta and Ventasso ionic measurements. No significant variations were observed regarding Cerelia ionic concentrations (Figure 7b). Ionic concentrations for Monte Cimone are shown in Figure 7c. Peaks appeared for ionic concentrations of Sulfate, Magnesium and Sodium, with their increases starting at the beginning of June 2012, after the major shocks. A considerable peak in ionic concentration of $\mathrm{Cl}^{-}$was observed at the end of April 2012.

Conductivity and $\mathrm{pH}$ of both Lieta and Ventasso were reported to have similar behaviors; both of their increases began at the time of the main shock. Conductivity levels weeks before the shocks reached minimum values for both Lieta and Ventasso around the time of the earthquakes. Additionally, $\mathrm{pH}$ levels of Lieta had the same behavior. However, paucity of data did not permit for a reliable interpretation of an association between conductivity and $\mathrm{pH}$ with earthquakes. Likewise, for Cerelia, a reliable interpretation could not be achieved regarding seismic activity. Whereas, for the Monte Cimone samples it was possible to extrapolate a define pattern of behavior due to the greater pool of data. In fact, $\mathrm{pH}$ measurements for Monte Cimone indicated both a net peak at the end of April 2012, corresponding to the $\mathrm{Cl}^{-}$peak, and an increase in $\mathrm{pH}$ during the main shocks. Moreover, the conductivity levels of Monte Cimone was seen to slightly decrease on May 10 and returned to normal values on June 10, 2012.

\section{Conclusions}

An association was observed between the May 20, May 29, June 3 and June 6, 2012, strong earthquakes and the pattern of increase for fluorescence intensity for the investigated Monte Cimone water samples. This pattern of increase started at the end of April 2012 and lasted until after June 6, 2012; the date of the last recorded strong earthquake. However, due to the low densities of available Lieta, Ventasso and Cerelia water samples taken before and after the main earthquakes, no association regarding between fluorescence peaks and seismic events could be investigated for. For the four sampled areas, no evidence of rainfall influence was detected. The first result of this study has been recently reported for tectonic areas in Turkey and Italy $[14,15]$. This result needs to be further investigated for its validity.

Regarding the conductivity results of our study, ionic concentrations showed some correlations with seismic activity. Even if the data were limited, we observed that for the Lieta samples the concentration levels of $\mathrm{Na}^{+}$, Sulfate and $\mathrm{Cl}^{-}$ions decreased during the weeks before the main shock and reached a maximum around May 20, 2012. More monotone increases were recorded for the Magnesium ion concentrations of Lieta and Ventasso. A sharp peck was observed in Potassium concentrations for Lieta, whereas a decrease in Nitrate was observed for Ventasso over the same period. Finally, a marked peak in ionic concentration for $\mathrm{Cl}^{-}$was observed at Monte Cimone at the end of April 2012. Concerning conductivity and $\mathrm{pH}$, they increased together starting from the main shock time for all the four bottled water plants. Moreover, a net peak of pH was measured at the end of April 2012, corresponding to the $\mathrm{Cl}^{-}$peak recorded for Monte Cimone. 
Citation: Fidani C, Balderer W, Leuenberger F (2017) The Possible Influences of the 2012 Modena Earthquakes on the Fluorescence Spectra of Bottled Mineral Water. Hydrol Current Res 8: 288. doi: 10.4172/2157-7587.1000288

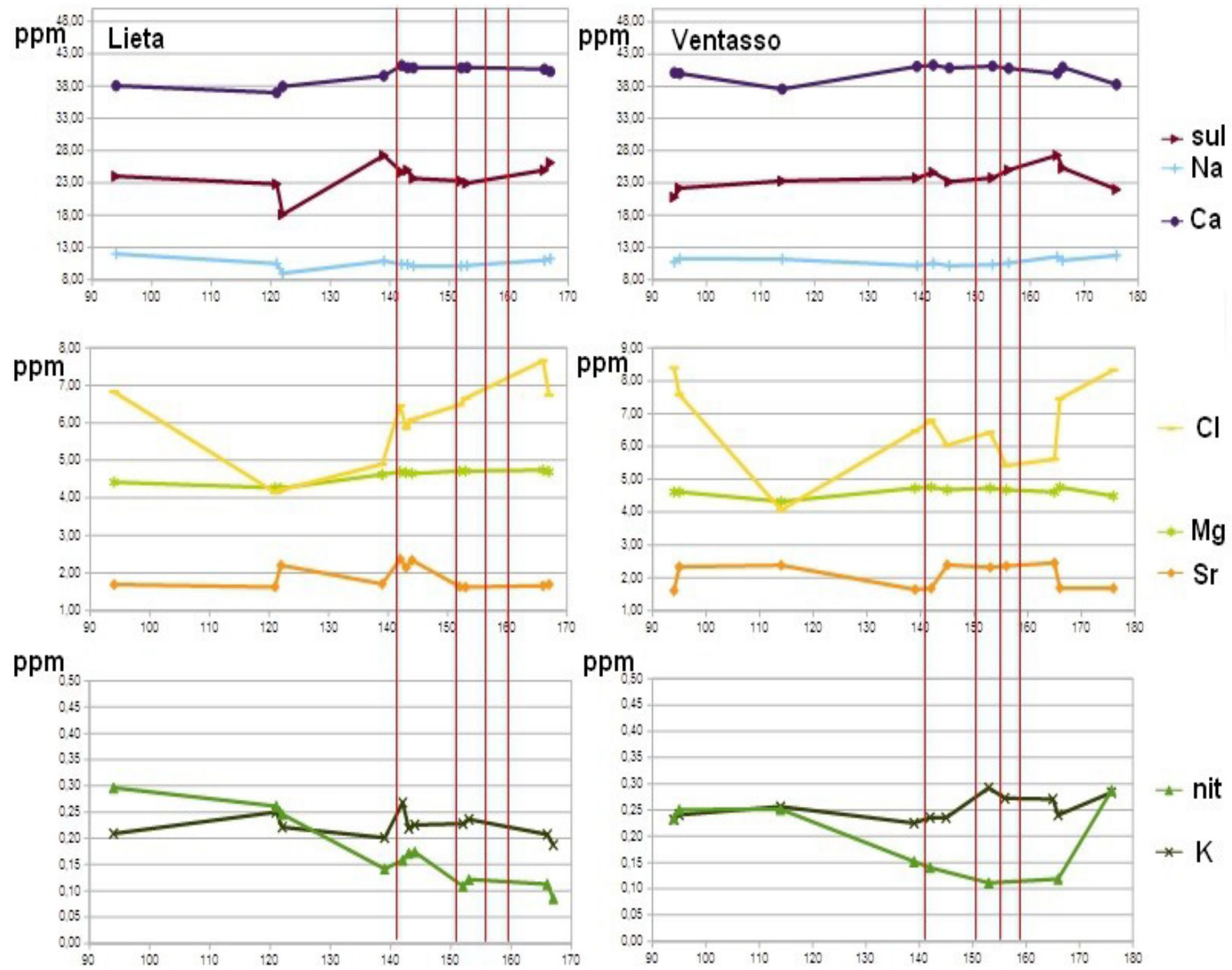

Figure 7a: Ionic content levels of Lieta and Ventasso. Earthquake times are indicated in red.

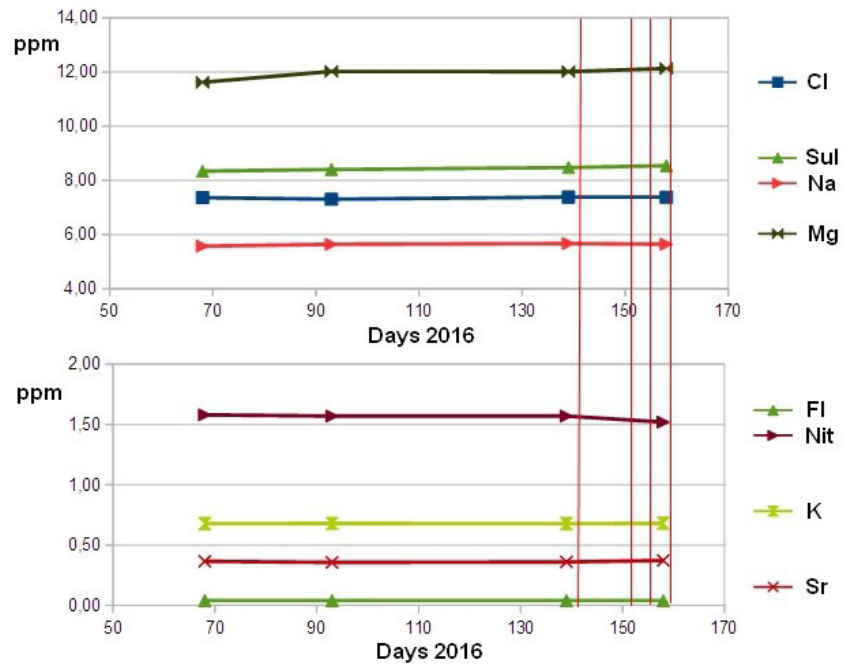

Figure $\mathbf{7 b}$ : Ionic content levels of Cerelia. Earthquake times are indicated in red.

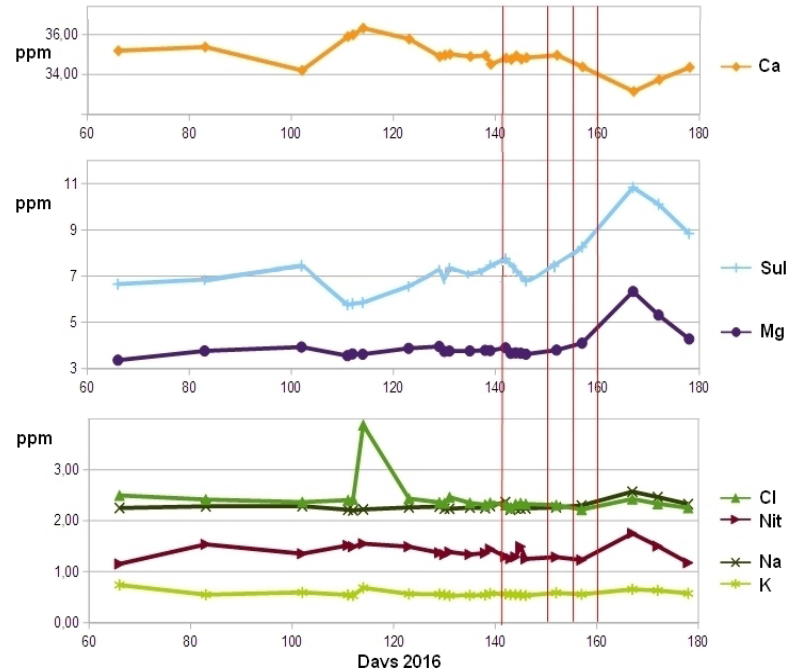

Figure 7c: Ionic content levels of Cimone. Earthquake times are indicated in red. 
Citation: Fidani C, Balderer W, Leuenberger F (2017) The Possible Influences of the 2012 Modena Earthquakes on the Fluorescence Spectra of Bottled Mineral Water. Hydrol Current Res 8: 288. doi: 10.4172/2157-7587.1000288
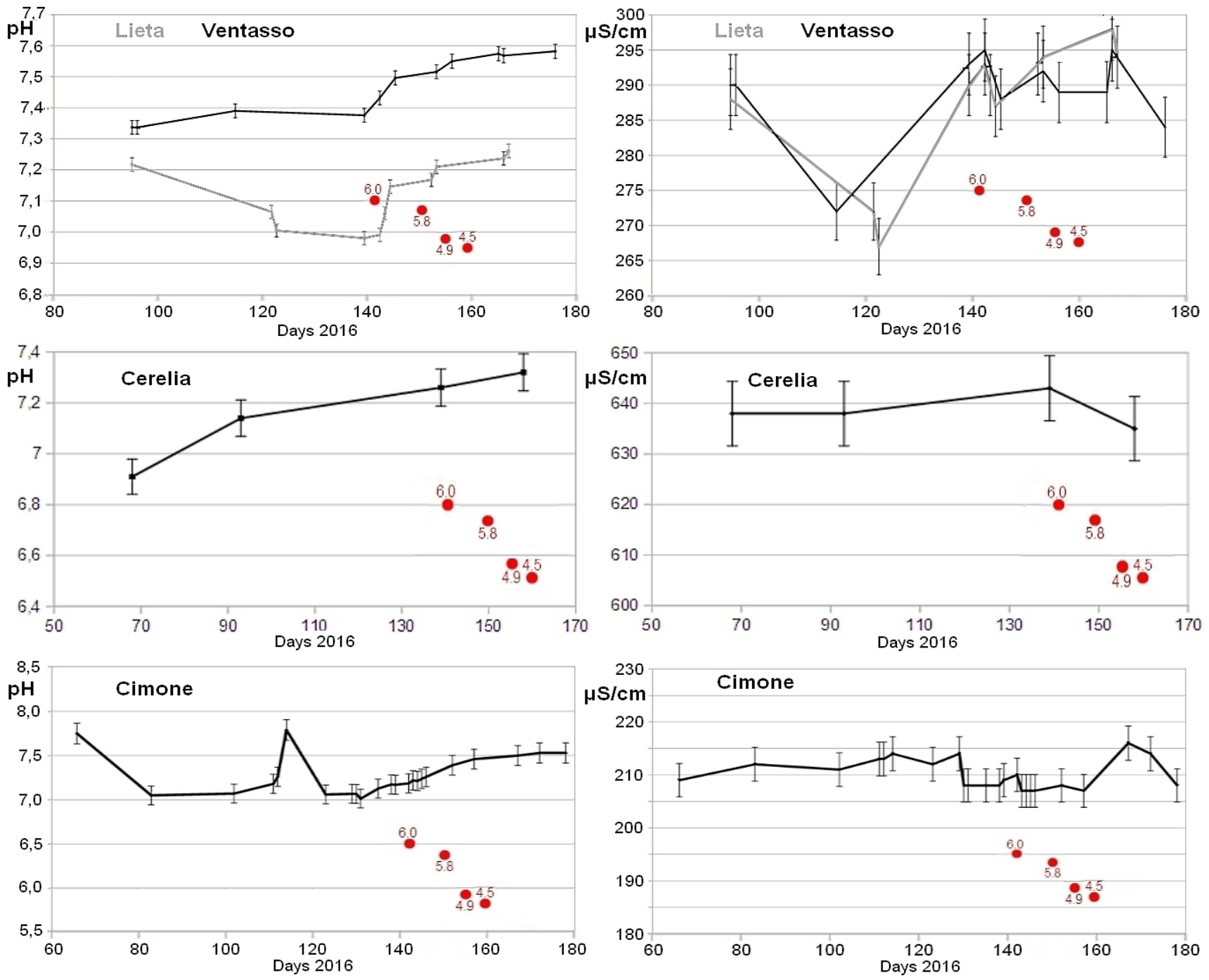

Figure 8: Earthquake times are shown in red. $\mathrm{pH}$ and conductivity of Ventasso, Lieta (grey lines), Cerelia and Monte Cimone are indicated in black.

What may be underlying these phenomena? Past investigations of loading rock blocks with high mechanical stress (as e.g., gabbro tiles) leading to electrical currents at their edges [29], have suggested hypotheses. Regarding the phenomena occurring around the time of strong earthquakes, it has been suggested that underlying there a solidstate physics interpretation. The process might combine the critical earthquake concept and the concept of crust acting as a charging electric battery under increasing stress [30-32]. Here, the electric charges are released by activation of dormant charge carriers in the oxygen anion sub lattice, called peroxy bonds or positive hole pairs. According to the cited experiments, the velocity of out flowing charges can reach $100 \mathrm{~m} / \mathrm{s}$. If these deep underground processes, in the form of stress accumulation in rocks have already begun before the onset of a strong earthquake, these processes could be associated with observed fluorescence changes in mineral waters sourced from the immediately surrounding areas; an average of $60 \mathrm{~km}$ from the main shocks.

\section{References}

1. Sornette D (1999) Earthquakes: From chemical alteration to mechanical rupture. Physics Reports 313: 237-291.
2. Hickman S, Sibons R, Bruhn R (1995) Introduction to special section: mechanical involvement of fluids in faulting. Journal of Geophysical Research 100: $12831-12840$

3. Kirby SH (1984) Introduction and digest to the special issue on chemical effects of water on the deformation and strength of rocks. Journal of Geophysical Research 89: 3991-3995.

4. Areshidze G, Bella F, Biagi PF, Caputo M, Chkuaseli V, et al. (1992) Anomalies in geophysical and geochemical parameters revealed on the occasion of Paravani $(M=5.6)$ and Spitak ( $M=6.9$ ) earthquakes (Caucasus). Tectonophysics 202: 23-41.

5. Hartmann J, Levy JK (2005) Hydrogeological and Gasgeochemical Earthquake Precursors - A Review for Application. Natural Hazards 34: 279-304.

6. Tsugonai U, Wakita H (1995) Precursory Chemical Changes in Ground Water Kobe Earthquake, Japan. Science 269: 61-62.

7. Wakita $H$ (1996) Geochemical challenge to earthquake prediction. Proc Nat Acad Sci USA 93: 3781-3786.

8. Pèrez NM, Hernandez PA, Igarashi G, Trujillo I, Nakai S, et al. (2008) Searching and detecting earthquake geochemical precursors in $\mathrm{CO}_{2}$-rich groundwaters from Galicia, Spain. Geochemical Journal 42: 75-83.

9. Inan S, Balderer WP, Leuenberger F, Yakan H, Özvan A, et al. (2012) 
Citation: Fidani C, Balderer W, Leuenberger F (2017) The Possible Influences of the 2012 Modena Earthquakes on the Fluorescence Spectra of Bottled Mineral Water. Hydrol Current Res 8: 288. doi: 10.4172/2157-7587.1000288

Springwater chemical anomalies prior to the $M w=7.2$ Van Earthquake (Turkey) Geochemical Journal 46: e11-e16.

10. Skelton A, Andren M, Kristmannsdottir H, Stockmann G, Morth CM, et al. (2014) Changes in groundwater chemistry before two consecutive earthquakes in Iceland. Nature Geoscience 7: 752-756.

11. Barberio MD, Barbieri M, Billi A, Doglioni C, Petitta M (2017) Hydrogeochemica changes before and during the 2016 Amatrice-Norcia seismic sequence (central Italy). Scientific Reports 7: 11735

12. Balderer W, Leuenberger F, Suner F, Stichler W (2002) Effects of the Cinarcik - Izmit August 17, 1999 earthquake on the composition of thermal and mineral waters as revealed by chemical and isotope investigations. Geofisica International 41: 433-437.

13. Balderer W, Leuenberger F, Stichler W, Yalcin T, Suner F, et al. (2006) Isotope Investigations of Thermal Water Systems in Western Turkey used as Benchmark Systems of Changing Conditions due to Tectonic Influences. Isotopic Assessment of Long Term Groundwater Exploitation- Proceedings of the final research coordination meeting held in Vienna, 122-16 May 2003, IAEA TEC DOC CD Series No. 1507, pp: 5-28.

14. Balderer W, Leuenberger F (2006) Observation of Fluorescence Spectra of Groundwater in Areas of Tectonic Activity: Could it act as a Precursor of Earthquakes? In: Geochemical Precursors for Earthquakes. Sen P, Das NK (eds.), McMillan, Kolkata, India, pp: 22-30.

15. Grant RA, Halliday T, Balderer WP, Leuenberger F, Newcomer M, et al. (2011) Ground Water Chemistry Changes before Major Earthquakes and Possible Effects on Animals. Int J Environ Res Public Health 8: 1936-1956.

16. Fäh D, Moore JR, Burjanek J, losifescu I, Dalguer L, et al. (2012) Coupled seismogenic geohazards in Alpine regions. Bollettino di Geofisica Teorica ed Applicata 53: 485-508.

17. Govoni A, Marchetti A, De Gori P, Di Bona M, Lucente FP, et al. (2014) The 2012 Emilia seismic sequence (Northern Italy): Imaging the thrust fault system by accurate aftershock location. Tectonophysics 622: 44-55.

18. Alessio G, Alfonsi L, Brunori CA, Burrato P, Casula G, et al. (2013) Liquefaction phenomena associated with the Emilia earthquake sequence of May- June 2012 (Northern Italy). Nat Hazards Earth Syst Sci 13: 935-947.

19. Sciarra A, Cantucci B, Buttinelli M, Galli G, Nazzari M, et al. (2012) Soil-gas survey of liquefaction and collapsed caves during the Emilia seismic sequence. Annals of Geophysics 55: 803-809.
20. Carminati E, Scrocca D, Doglioni C (2010) Compaction-induced stress variations with depth in an active anticline: Northern Apennines, Italy. Journal of Geophysical Research 115: B02401.

21. Ventura G, Di Giovambattista R (2013) Fluid pressure, stress field and propagation style of coalescing thrusts from the analysis of the 20 May 2012 ML5.9 Emilia earthquake (Northern Apennines, Italy). Terra Nova 25: 72-78.

22. ARPA Regione Emilia Romagna (2015) Servizio Idrometeorologico Area Idrologica, Annali Idrologici 2012, Parte Prima.

23. Reutter KJ, Giese P, Closs H (1980) Lithospheric split in the descending plate: observations from the Northern Apennines. Tectonophysics 64: T1-T9.

24. Fantoni R, Franciosi R (2010) Tectono-sedimentary setting of the Po Plain and Adriatic foreland. Rend Fis Acc Lincei 21: 197-209.

25. Margheriti L, Azzara R, Cocco M, Delladio A, Nardi A (2000) Analyses of borehole broadband recordings: test site in the Po basin, Northern Italy. Bull Seismol Soc Am 90: 1454-1463.

26. Lakowicz JR (2006) Principles of fluorescence spectroscopy. Springer, New York, USA, 3rd edn.

27. Dobrovolsky IP, Gershenzon NI, Gokhberg MB (1989) Theory of electrokinetic effects occurring at the final stage in the preparation of a tectonic earthquake. Phys Earth Planet Int 57: 144-156.

28. Scoville J, Sornette J, Freund FT (2015) Paradox of peroxy defects and positive holes in rocks Part II: Outflow of electric currents from stressed rocks. Journal of Asian Earth Sciences 114: 338-351.

29. Freund $F(2002)$ Charge generation and propagation in rocks. J Geodyn 33 545-572.

30. Freund FT, Takeuchi A Lau BW (2006) Electric currents streaming out ofstressed igneous rocks- a step towards understanding pre-earthquake low frequency EM emissions. Phys Chem Earth 31: 389-396.

31. Freund FT (2007) Pre-earthquake signals- Part II: flow of battery currents in the crust. Nat Hazards Earth Syst Sci 7: 1-6.

32. Freund F, Pilorz S (2012) Electric currents in the earth crust and the generation of pre-earthquake ULF signals. In: Hayakawa M (ed.), Frontier of Earthquake Prediction Studies. Nippon, Shuppan, Tokyo, pp: 464-508. 